\title{
Evaluation of SV40 in osteosarcoma and healthy population: A Hungarian-German study
}

\author{
SUSANNE HEINSOHN ${ }^{1}$, MIKLOS SZENDROI ${ }^{2}$, STEFAN BIELACK ${ }^{3,4}$, \\ UDO ZUR STADT ${ }^{1}$ and HARTMUT KABISCH ${ }^{1}$
}

\begin{abstract}
${ }^{1}$ University Medical Centre Hamburg-Eppendorf, Centre for Women's and Children's Health, Department of Paediatric Haematology and Oncology, Martinistr. 52, D-20246 Hamburg, Germany; ${ }^{2}$ Department of Orthopaedics of Semmelweis University of Budapest, XI. Karolina ut 27, 1113 Budapest, Hungary; ${ }^{3}$ Clinic Stuttgart-Paediatrics 5 (Oncology, Haematology, Immunology), Olgahospital, Bismarckstr. 8, 70176 Stuttgart; ${ }^{4}$ University Children's Hospital Muenster, Department of Paediatric Haematology and Oncology, Albert-Schweitzer-Strasse 33, 48149 Muenster, Germany
\end{abstract}

Received September 8, 2008; Accepted October 27, 2008

DOI: $10.3892 /$ or_00000220

\begin{abstract}
Simian virus 40 (SV40) has been linked to human cancer, as has osteosarcoma (OS). Although significant discrepancies exist in the frequency, evidence that the virus plays a causative role in some malignancies is mounting. The large-T-antigen and significant SV40 oncoprotein, bind and inactivate the tumour suppressor genes p53 and pRb, which play a key role in osteosarcoma development. We analysed 277 OS samples from two different European countries (154 OS samples from Hungary and 123 from Germany). To ascertain the prevalence of SV40 in the general population, additional blood samples from healthy volunteers from the two countries (166 Hungarian and 149 German) were analysed. To reach an appropriate detection level, we investigated a real-time quantitative PCR-based assay for the detection and quantification of SV40 <10 copies in $500 \mathrm{ng}$ of genomic DNA. We detected SV40 in 52\% (143/277) of the OS samples analysed. In detail, we saw differences in the distribution of SV40 between the two countries. Of the Hungarian OS samples, 74\% (114/154) showed high amounts of SV40 (>100 copies), whereas only $22 \%$ (29/123) of the German OS samples harbour small amounts of SV40 ( 10 copies). SV40 was detected in 8 of 60 German tumour samples (14\%) and 21 of 63 German blood samples (33\%) from OS patients. In the peripheral blood of healthy volunteers we found only weak SV40 positivity ( $<10$ copies) in the two countries with
\end{abstract}

Correspondence to: Dr Susanne Heinsohn, University Medical Centre Hamburg-Eppendorf, Centre for Women's and Children's Health, Department of Paediatric Haematology and Oncology, Martinistr. 52, D-20246 Hamburg, Germany

E-mail: heinsohn@uke.uni-hamburg.de

Key words: simian virus 40, large T-antigen, real-time quantitative PCR, osteosarcoma a somewhat higher frequency in Hungarian 30/166 (18\%) than in German blood samples 2/149 (1.3\%). No sequence variations were found in SV40-positive samples from the two countries. Our data demonstrate significant differences in the prevalence and quantity of SV40 in OS of these different European geographical origins with a lower frequency in the blood samples of healthy volunteers from the two countries, underlining again the geographical differences previously described by other investigators.

\section{Introduction}

Osteosarcoma (OS) is the most frequent bone malignancy in children and adolescents, mostly occurring in the second decade of life and peaking around the age of 14 years. Multiple molecular lesions underline the progression from normal bone to osteosarcoma. Coexisting alterations of the retinoblastoma susceptibility (pRb) and the p53 gene are known to be important events in this progression (1-5). Different investigations have identified DNA sequences of simian virus 40 (SV40) in osteosarcomas suggesting that this virus contributes to the development of this tumour (6-8). Rare epidemiological studies exist, showing a direct correlation of human cancer to viral contamination (9). This is evident for the role of SV40 in human tumorigenesis as well as in osteosarcoma development, which remains controversial in the literature.

SV40 is a DNA-polyomavirus of rhesus macaque origin, known to be a potent tumour-inducing virus (10-15). It is also capable of transforming many types of cells in tissue culture, including human cells (16). Its oncogenecity is mediated by the large T-antigen (L-Tag), a $90 \mathrm{kDa}$ nuclear multifunctional phosphoprotein that is predominantly located in the nuclei of the infected cells. It binds and inhibits several host-cell proteins, for example tumour suppressor genes such as $\mathrm{pRb}$ and p53, as well as transcriptional co-activators. P53 and pRb normally function as regulators of growth control and cell cycling (17-19) and are known to play a key role in the genesis of multiple tumours, as has been shown for osteosarcoma development. By binding them, L-Tag inactivates their normal function. L-Tag is also known to cause a large number of 
chromosomal aberrations, rearrangements, damage and mutations in SV40-infected human cells (20).

The history of SV40 infection in humans appears to be related to the use of polio vaccines. The inactivated and live attenuated forms of the polio vaccine were prepared in primary rhesus monkey kidney cells, some of which were from animals naturally infected with SV40, a virus which was unknown at that time. Therefore, millions of humans were unintentionally exposed to live SV40-contaminated polio vaccines worldwide during the period of mass vaccination between 1955 and 1963 (9,20-23). Since then, SV40 has continued to circulate in the human population, including Germany and Hungary $(5,24)$. It has been suggested that the monkey virus is transmitted by those given the contaminated vaccine to their children, further spreading the potential cancer risk in humans. It is also known that SV40 replicates in humans and is excreted in faeces, urine and sperm.

Shortly after its discovery in 1960 (26), SV40 was found to be tumorigenic in animals $(11,14)$. In these laboratory animals, SV40 has induced specific tumours in the brain and bone, as well as mesotheliomas and lymphomas. Early studies of small cohorts of patients showed that SV40 was capable of establishing infections in humans (20). Studies from different countries (USA, Europe, China and Japan) have indicated that SV40 is significantly associated with some specific human cancer types such as those found earlier in laboratory animals (brain tumours, osteosarcoma, mesotheliomas and lymphomas). Evidence for the role of SV40 in these specific tumour types is mounting (27-35). SV40 incidence in these tumours differs considerably by geographic region, for osteosarcoma, e.g. between 5\% (Houston, USA) (20) and 80\% (Italy) (6).

However, although currently it is poorly understood, it is important to investigate the status of SV40 infections in different populations $(36,37)$. Importantly, SV40 was isolated from a primary brain cancer of a 4-year-old child (38). Many of the SV40-positive specimens were derived from humans who were too young to have been directly exposed to the contaminated polio vaccines $(39,40)$, raising the possibility that SV40 has entered the human population and become a new and emergent pathogen.

SV40 prevalence in osteosarcoma patients of German origin was previously studied in our lab, using conventional PCR followed by Southern hybridisation and sequencing. These data showed only a very low SV40 incidence of only $4 \%$ (41). SV40 quantification was not part of that investigation. The development of a very sensitive real-time quantitative PCR assay allowed us to re-evaluate the role of SV40 in human cancer $(42,43)$; in this investigation specifically in osteosarcoma. Therefore, we investigated a larger number of osteosarcoma samples from Germany and Hungary, respectively, with a different polio vaccination profile in each country (Table I) (44). Additionally, comparable numbers of blood samples from healthy volunteers of the two countries were examined to analyse the distribution of SV40 in the general population and obtain the background of the SV40 infection rate in healthy subjects. This is important when critically examining and appraising the results, as well as discussing the possible role of SV40 in the pathogenesis of OS development.

\section{Materials and methods}

\section{Subjects and specimens}

Hungarian specimens. The 154 osteosarcoma specimens from Hungary $(\mathrm{Hu})$ were obtained from the Department of Orthopaedics of the Semmelweis University of Budapest (Hungary), where $70 \%$ of the Hungarian osteosarcoma cases were treated. Patients involved in the study were born between 1920 and 1993 (68 female and 86 male). The investigated osteosarcomas were diagnosed between 1971 and 2001. The Hungarian osteosarcoma specimens had been paraffinembedded and evaluated for sufficient content of vital tumour cells by microscopic examination in Hungary.

The investigated osteosarcoma tumours were mostly located at the distal femur (67) and proximal tibia (36). Locations are also at the humerus proximal (14), the fibula proximal (7) and at the ileum (12), pedis (3), sacrum (3) and 12 different other locations.

Clinical characteristics of the investigated osteosarcomas were derived from Semmelweis University, Budapest. From each paraffin block, 10 slices were cut off and transferred to sterile vials, on different days by different technical assistants and in different laboratories of the Semmelweis University Hospital in Budapest to avoid contamination by cutting procedure and laboratory staff.

Fresh peripheral blood was taken from healthy blood donors born between 1919 and 1990 in Hungary (110 female and 56 male) and collected in the blood transfusion centre of the Semmelweis University Hospital, Budapest. Handling of the blood samples from healthy volunteers, as well as that of patient and volunteer data was according to the ethics commission from Budapest. Collected slices as well as fresh blood samples were transferred to Hamburg where DNA isolation and an SV40 analysis were carried out.

German specimens. German (Ger) osteosarcoma specimens were obtained from different collaborating COSS (Cooperative osteosarcoma study) centres. Fresh tumour samples were examined postoperatively by a pathologist, evaluated for sufficient content of vital tumour cells, frozen in liquid nitrogen and stored at $-70^{\circ} \mathrm{C}$ until DNA isolation was performed. We investigated 123 samples from 75 osteosarcoma patients born between 1947 and 2002 and their osteosarcomas were diagnosed between 1979 and 2004. The 123 specimens consist of 60 tumour (Tu) and 63 blood (PBL) samples. From 35 patients, Tu as well as PBL were analysed and from 40 patients we analysed either Tu or PBL.

The investigated osteosarcoma tumours were mostly located at the distal femur and at the proximal tibia, as were the Hungarian samples. Other locations correspond to the spreading as indicated in the COSS protocols and are similar to those of Hungary.

Clinical characteristics of the investigated osteosarcomas were derived from the Co-operative Osteosarcoma Study Group (COSS). The handling of the data was conducted according to the ethics commission from 1996 during the COSS-96 study protocol and the corresponding research analysis.

The 149 fresh buffy coats from healthy German people, born between 1939 and 1985 (96 female and 53 male) were 
Table I. History of vaccination against poliomyelitis in Hungary and Germany.

\begin{tabular}{|c|c|c|c|}
\hline $\begin{array}{l}\text { Germany: } \\
\text { birth } \geq 1940\end{array}$ & Poliovaccines used in Germany & $\begin{array}{l}\text { Hungary: } \\
\text { birth } \geq 1938\end{array}$ & Poliovaccines used in Hungaryc \\
\hline $1956-1960$ & IPV from Parke Davis (Canada) SV40+ & $1957-1959$ & IPV from Connaught (Canada) SV40+ \\
\hline Since 1960 & $\begin{array}{l}\text { IPV tested for SV40 } \\
\text { contamination }\end{array}$ & $1959-1960$ & $\begin{array}{l}\text { IPV from Russian production (IPVEa } \\
\text { Moscow) }\left(\mathrm{SV}^{\mathrm{a}} 40^{+}\right)\end{array}$ \\
\hline \multirow[t]{2}{*}{ Since 1962} & $\begin{array}{l}\text { OPV from Lederle, German production } \\
\text { SV40-free }\end{array}$ & $1961-1962$ & $\begin{array}{l}\text { OPV from Hungarian production }\left(\mathrm{NIPH}^{\mathrm{b}} \text {, }\right. \\
\text { Budapest) }\end{array}$ \\
\hline & & Since 1963 & $\begin{array}{l}\text { OPV from Russia production (IPVE }{ }^{\mathrm{a}} \text {, } \\
\text { Moscow) }\end{array}$ \\
\hline
\end{tabular}

aPVE, Institute of poliomyelitis and viral encephalitis; ${ }^{\mathrm{a}} \mathrm{NIPH}$, National Institute of Public Health; ${ }^{\mathrm{c}}$ The information on Hungary was taken from (44); IPV, inactivated polio vaccine (Salk) and OPV, oral polio vaccines (Sabin).

obtained from the blood transfusion centre at the University Medical Centre in Hamburg-Eppendorf (Germany). The SV40 results of this group were described previously (42).

Control samples. The SV40-transformed COS-1 cell line (African green monkey kidney cells), with one integrated copy of the complete early region of SV40 including its transcriptional control region (45), was used as a positive control. In order for the paraffin-embedded specimens from Hungary to serve as an adequate control, this cell line was paraffin-embedded prior to DNA extraction.

DNA from the buffy coat of healthy individuals, previously tested as SV40 negative by RQ-PCR, was utilised as a negative control in each RQ-PCR experiment as well as for dilution of the genomic DNA.

Paraffin embedding of the control cell line. A COS-1 cell line was cultured for sufficient cells and pelleted. The cell pellet was resuspended in $4 \%$ formalin (in $0.1 \mathrm{M}$ phosphate buffer) and incubated for $2 \mathrm{~h}$ at room temperature. After washing twice with $0.1 \mathrm{M}$ phosphate buffer, the cell pellet was resuspended in $2 \%$ agar. After freezing, the agar block was paraffinembedded in the same manner as a biopsy. The block was cut into slices and the DNA extraction was examined according to the protocol for paraffin-embedded osteosarcoma specimens.

DNA extraction. Genomic DNA was extracted from fresh or frozen cells ( $1 \times 10^{7}$ for each sample) using Qiagen silica gelbased spin columns (QiaAmp DNA blood mini/midi kit; Qiagen, Hilden, Germany) according to the 'blood and body fluid protocol', following the supplier's recommendation. DNA from frozen and paraffin-embedded tissues (5 samples of $10 \mu \mathrm{m}$ for each sample) was isolated using the DNA spin column extraction according to the 'QiaAmp tissue protocol'. Paraffin samples were deparaffinized with xylene, followed by two washing steps with $70 \%$ ethanol prior to DNA extraction. In the case of paraffin samples, lysis overnight was not sufficient in most cases. Therefore, 2-3 days were necessary to ensure sufficient lysis.
DNA extraction using silica gel-based spin columns was tested by the investigators and found to be adequate for extracting very low copy numbers of extra chromosomal virus particles (42).

Real-time quantitative PCR (RQ-PCR) analysis. The COS-1 cell line, well described by Gluzman (45), has one single integrated SV40 copy and was therefore used as a quantification standard. Serial 10-fold dilutions of a DNA cell line, mixed with SV40-negative DNA from healthy controls to achieve equal amounts of DNA in each dilution sample (500 ng per reaction), were used to create a standard curve.

The integrity and quality of the DNA was tested by amplifying the B-globin gene with an internal Taq Man-probe. Only samples with a CT-value of $20 \pm 1(25 \pm 1$ cycles for DNA samples derived from paraffin wax) were selected for quantification. Samples were analysed in triplicate. In the case of SV40 positivity, analysis was repeated as 6-fold and, in part, 9-fold reactions. Detailed RQ-PCR reaction and amplification conditions were previously described by Heinsohn et al (42).

Sequence analysis of $R Q-P C R$ products. To further verify the results, DNA sequence analysis was performed in selected SV40-positive tumour samples and in the positive controls. SV40-positive PCR products were extracted from LightCycler capillaries used for real-time PCR, and were finally sequenced as described previously (42).

\section{Results}

We analysed the presence of SV40 sequences in samples from osteosarcoma patients as well as in a larger series of blood samples from healthy volunteers from Hungary and Germany, which had a different profile in polio mass vaccination. The year of birth of the osteosarcoma patients and the healthy control group ranged at approximately the same period of time for the two countries. Hungarian osteosarcoma patients were born between 1920 and 1993, and Hungarian healthy volunteers between 1919 and 1990. German osteosarcoma 
Table II. Results are given for samples from osteosarcoma and healthy donors for two European countries, and the SV40 quantity is indicated by copy numbers.

\begin{tabular}{|c|c|c|c|c|c|c|c|c|c|}
\hline \multirow{2}{*}{$\begin{array}{l}\text { Samples, } \\
\text { year of disease }\end{array}$} & \multirow[b]{2}{*}{ Type of specimens } & \multirow[b]{2}{*}{ Year of birth } & \multirow[b]{2}{*}{$\mathrm{n}$} & \multirow{2}{*}{$\begin{array}{c}\mathrm{SV}_{40}^{+} \\
\text {total }\end{array}$} & \multirow{2}{*}{$\begin{array}{l}\mathrm{SV} 40^{+} \\
\%\end{array}$} & \multicolumn{4}{|c|}{ SV40 quantity (copies) } \\
\hline & & & & & & $<1000$ & $100-1000$ & $<100$ & $<10$ \\
\hline $\begin{array}{l}\text { Osteosarcoma } \\
\text { (Hungary) 1971-2001 }\end{array}$ & $\begin{array}{l}\text { Paraffin-embedded } \\
\text { tissue }\end{array}$ & $1920-1993$ & 154 & $114 / 154$ & 74 & 6 & 51 & 41 & 16 \\
\hline $\begin{array}{l}\text { Healthy population } \\
\text { (Hungary) }\end{array}$ & $\begin{array}{l}\text { Fresh peripheral } \\
\text { blood }\end{array}$ & $1919-1990$ & 166 & $30 / 166$ & 18 & & & & 32 \\
\hline $\begin{array}{l}\text { Osteosarcoma } \\
\text { (Germany) } \\
1979-2004\end{array}$ & $\begin{array}{l}\text { Fresh-frozen } \\
\text { tumour or blood }\end{array}$ & $1947-2002$ & $\begin{array}{c}123 \\
\text { TU:60 } \\
\text { PB:63 }\end{array}$ & $\begin{array}{l}29 / 123 \\
8 / 60 \\
21 / 63\end{array}$ & $\begin{array}{l}22 \\
14 \\
33\end{array}$ & & & & 29 \\
\hline $\begin{array}{l}\text { Healthy population } \\
\text { (Germany) }\end{array}$ & $\begin{array}{l}\text { Fresh peripheral } \\
\text { blood }\end{array}$ & $1939-1985$ & 149 & $2 / 149$ & 1.4 & & & & 2 \\
\hline $\begin{array}{l}\text { Control cell line } \\
\text { COS-1 (monkey) }\end{array}$ & $\begin{array}{l}\text { Fresh- and paraffin- } \\
\text { embedded cells }\end{array}$ & & & & 100 & $\mathrm{x}$ & & & \\
\hline
\end{tabular}

Table III. SV40 outcome in blood samples derived from healthy donors in Hungary and Germany by birth cohorts.

\begin{tabular}{lccc}
\hline Birth cohorts & $\begin{array}{c}\text { No. of samples } \\
(\mathrm{Hu} / \mathrm{Ger})\end{array}$ & $\begin{array}{c}\mathrm{SV} 40^{+}(\%) \\
(\mathrm{Hu} / \mathrm{Ger})\end{array}$ & $\begin{array}{c}\mathrm{SV} 40^{+}(\mathrm{f} / \mathrm{m}) \\
(\mathrm{Hu} / \mathrm{Ger})\end{array}$ \\
\hline $1910-1919$ & $1 / 0$ & $0(0)$ & $0 / 0$ \\
$1920-1929$ & $11 / 0$ & $2(18)$ & $1 / 1$ \\
$1930-1939$ & $20 / 5$ & $5(25)$ & $4 / 1$ \\
$1940-1949$ & $42 / 33$ & $5(12)$ & $4 / 1$ \\
$1950-1959$ & $39 / 30$ & $9(23)-2(1.4)$ & $3 / 6-1 / 1$ \\
$1960-1969$ & $19 / 27$ & $1(5.2)$ & $1 / 0$ \\
$1970-1979$ & $27 / 24$ & $8(29)$ & $5 / 3$ \\
$1980-1989$ & $6 / 30$ & $0(0)$ & $0 / 0$ \\
$1990-2000$ & $1 / 0$ & $0(0)$ & $0 / 0$ \\
Total & $166 / 149$ & $30(18)-2(1.4)$ & $18 / 12-1 / 1$ \\
\hline
\end{tabular}

f, Female; m, male; Hu, Hungary and Ger, Germany.

patients were born between 1958 and 1993, and German healthy donors between 1939 and 1985 .

SV40 in osteosarcoma. We found SV40 in 114 of $154(74 \%)$ Hungarian osteosarcoma tumour samples in $>100$ copies (in part $>1000$ copies, examples are shown in Fig. 3) compared to $<10$ copies in 29 of $123(22 \%)$ samples from 75 osteosarcoma patients of German origin: 8/60 (14\%) in tumours and 21/63 (33\%) in peripheral blood samples (Fig. 4).

Distribution of SV40 positivity in Hungarian osteosarcoma samples during the given decades is high with $84 \%$ in the 1970 s, $66 \%$ in the 1980 s, and $75-78 \%$ from 1990 to 2001. SV40 positivity in German osteosarcomas is $\sim 12 \%$ in the
Table IV. SV40 prevalence in osteosarcoma samples from Hungary and Germany in relation to the year of diagnosis.

\begin{tabular}{lcc}
\hline $\begin{array}{l}\text { Year of } \\
\text { diagnosis }\end{array}$ & $\begin{array}{c}\text { No. of samples } \\
\text { (Hungary/Germany) }\end{array}$ & $\begin{array}{c}\text { SV40 }(\%) \\
\text { (Hungary/Germany) }\end{array}$ \\
\hline $1971-1979$ & $13 / 8$ & $11(84) / 1(12)$ \\
$1980-1889$ & $59 / 25$ & $39(66) / 3(12)$ \\
$1990-1999$ & $70 / 54$ & $55(78) / 14(25)$ \\
$2000-2004$ & $12 / 21$ & $9(75) / 6(28)$ \\
Total & $154 / 108$ & $114(74) / 24(22)$ \\
\hline
\end{tabular}

1970s and the same in the 1980s, respectively. At later time points, SV40 prevalence on osteosarcomas in Germany increases in 1990, is $25 \%$ during the 1990 s and $28 \%$ during the period since 2000 (Fig. 2, Table IV).

SV40 in healthy population. In healthy volunteers we found weak SV40 positivity (<10 copies) in 30/166 (18\%) Hungarian and 2/149 (1.3\%) German blood samples (Table II, Fig. 5).

From the Hungarian healthy volunteers, 32 individuals were born before 1938, the year polio mass vaccination started in Hungary (6 of whom were SV40-positive) and 134 were born after 1938 (24 of whom were SV40-positive). Hungarian people born since 1938, and those born in Germany since 1940 had been polio-vaccinated (Table I).

The SV40-positive healthy donors from Hungary were born between 1927 and 1976. German osteosarcoma patients were born between 1958 and 1993, and German healthy donors between 1939 and 1985. The two SV40-positive German samples from healthy volunteers were from donors born in 1958 and 1959. No significant differences in SV40 prevalence between the birth cohorts during the given time 


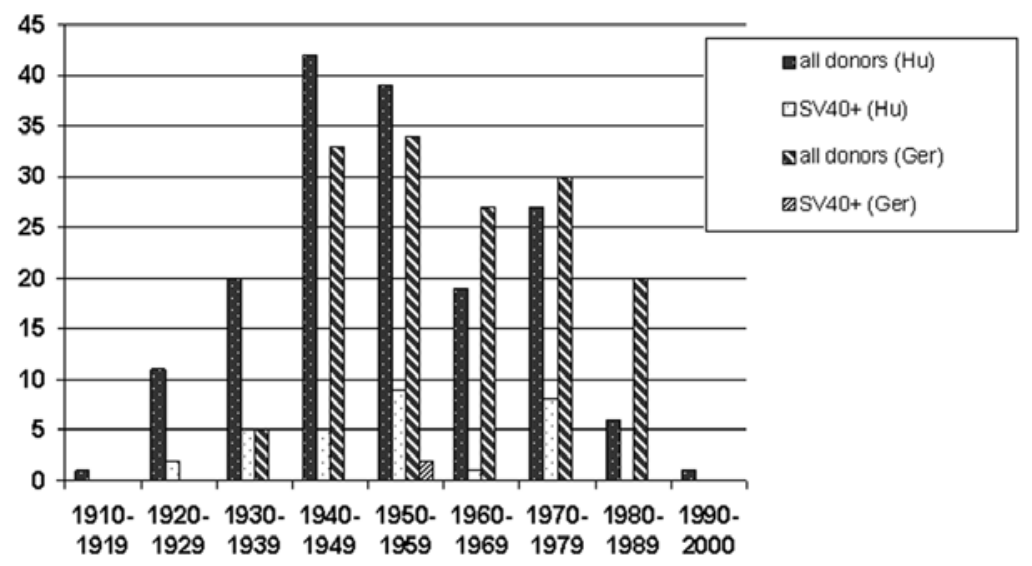

Figure 1. SV40 outcome in blood samples derived from healthy donors in Hungary and Germany by birth cohorts.

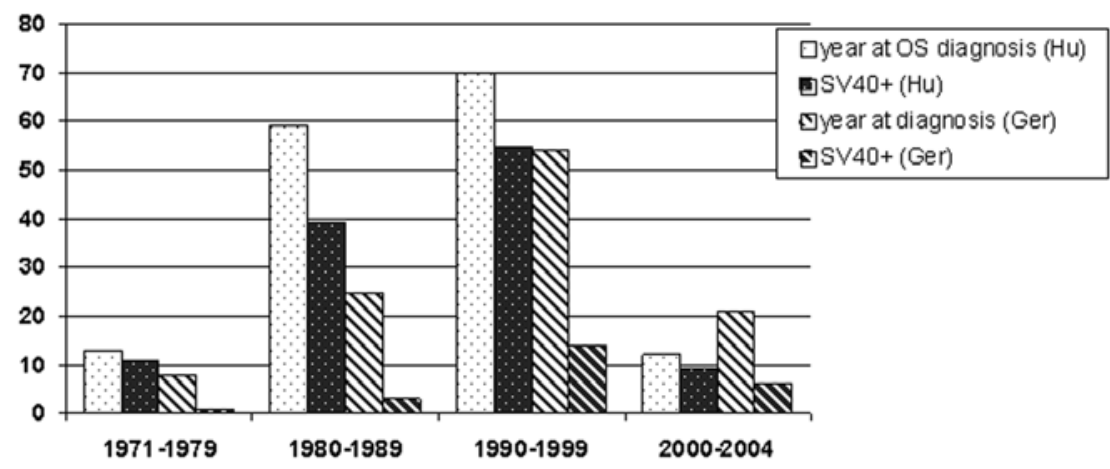

Figure 2. Diagnosis of SV40 in osteosarcomas from Hungary and Germany, given in decades.

\section{SV40 in Osteosarcoma samples in Hungary}

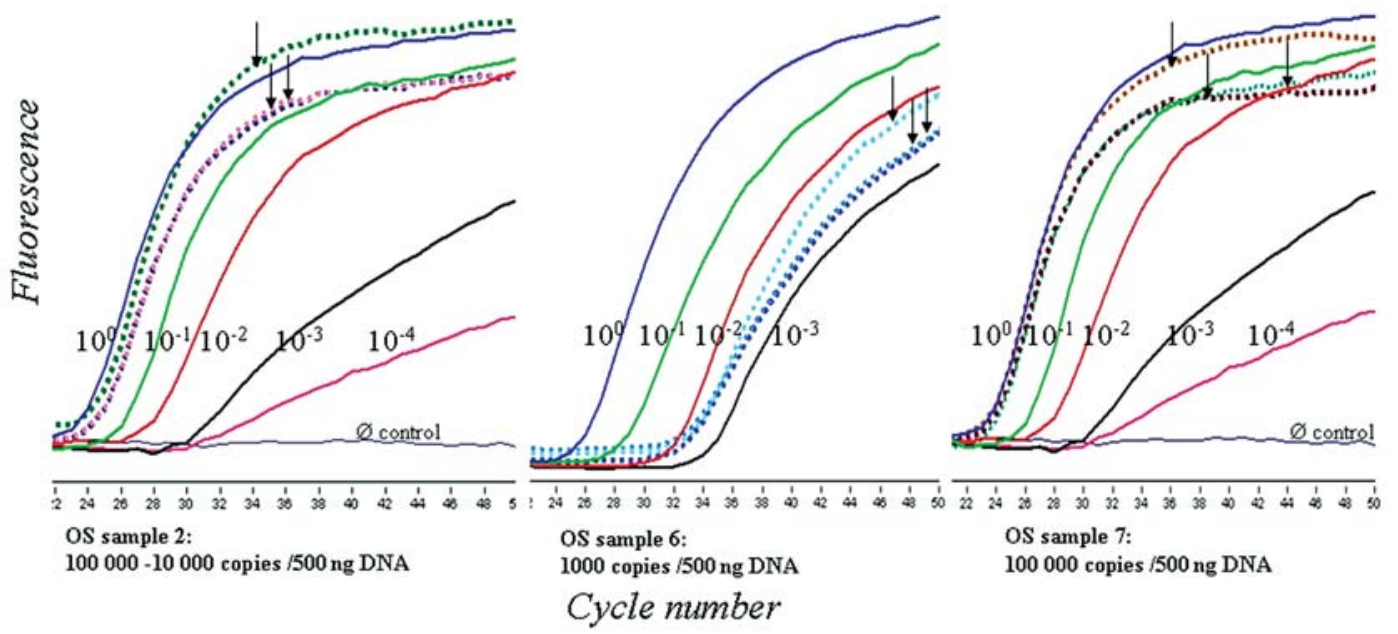

Figure 3. RQ-PCR curves indicating SV40 in 3 examples derived from paraffin-embedded osteosarcoma samples from Hungary. Serial 10-fold dilution of the control cell line COS-1 (in this case paraffin-embedded prior to DNA extraction) which served as a quantification standard of $<10-3$ and, in part, 10-4. Positive samples are indicated by the dotted lines and arrows.

periods were found in the two countries (Table III, Fig. 1). The distribution between SV40 positivity from male donors with $21 \%(12 / 56)$ and female donors with $18 \%(20 / 110)$ is comparable to Hungary (data not shown). The two SV40- positive healthy donors from Germany are female (Table III, Fig. 1).

Due to the high homology existing between the DNA of SV40, JC-virus (Jacob-Creutzfeld virus) and BK-virus (BK 


\section{SV40 in Osteosarcomas in Germany}

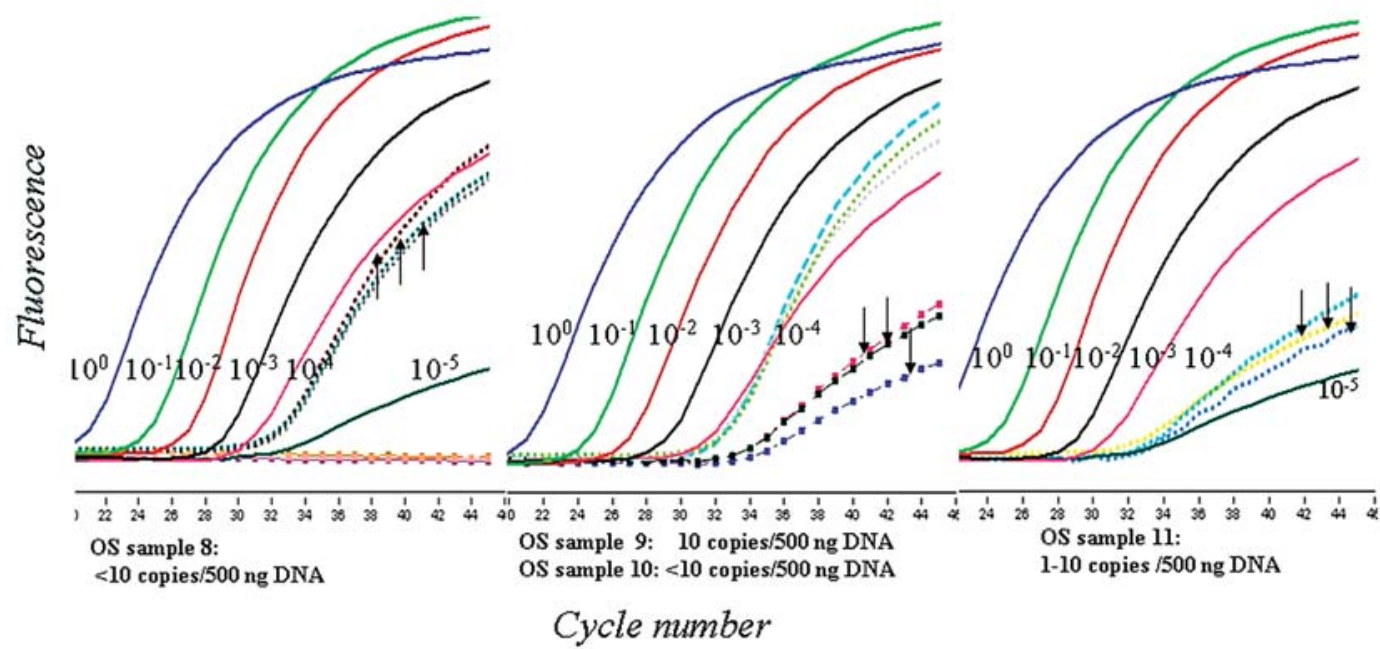

Figure 4. RQ-PCR curves indicating SV40 in 4 examples derived from fresh-frozen osteosarcoma samples from Germany. Serial 10-fold dilution of the control cell line COS-1 which served as a quantification standard of <10-4 and, in part, 10-5. Positive samples are indicated by the dotted lines and arrows.

\section{SV40 in healthy individuals of both countries}

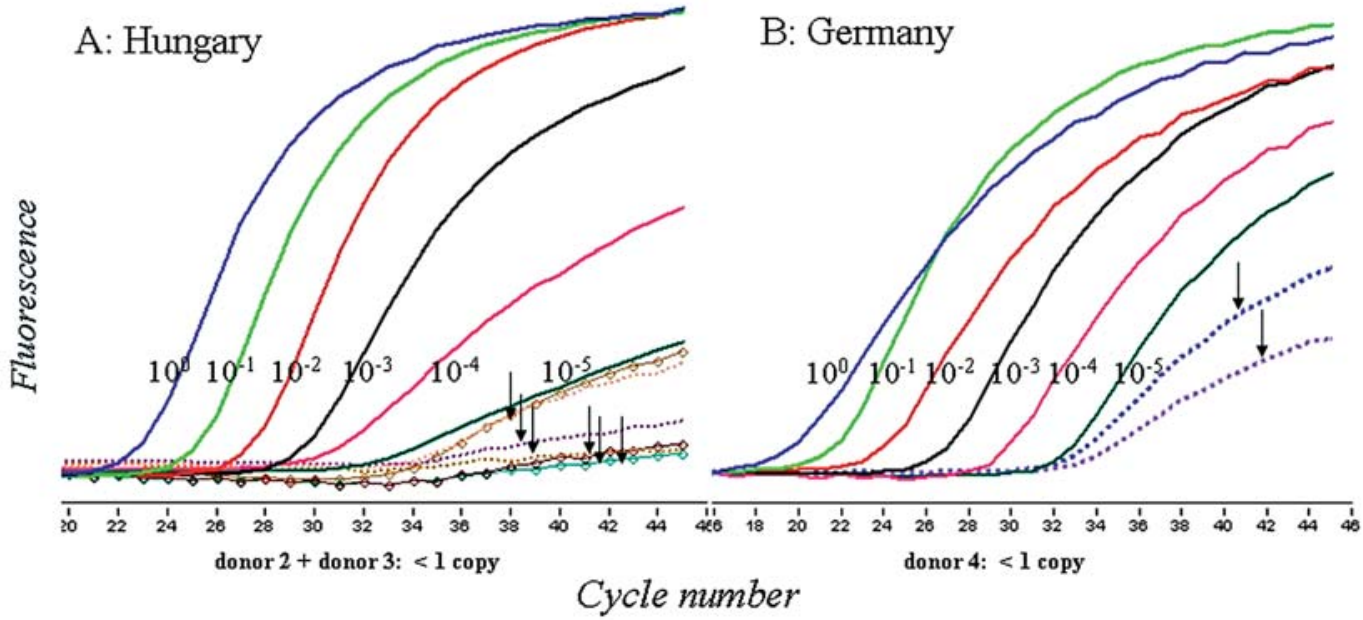

Figure 5. RQ-PCR curves indicating SV40 in examples derived from fresh blood samples derived from healthy individuals of (A) Hungary and (B) Germany. Serial 10-fold dilution of the control cell line COS-1 which served as a quantification standard of <10-4 and, in part, 10-5. Positive samples are indicated by the dotted lines and arrows.

from the initials of the first patient from which this virus was isolated), the identity of the RQ-PCR results were confirmed by sequencing in several cases. No sequence variation was found between SV40-positive osteosarcoma samples from Hungary and Germany, nor between SV40-positive healthy volunteers of the two countries. No SV40 sequence variations were found between SV40-positive samples derived from people born before or after the beginning of polio mass vaccination in the two countries. None of the samples showed sequence homology to either JCV or BKV sequences. Hybridisation with a specific internal SV40 probe, occurred simultaneously with real-time PCR as a further verification step. The results of these analyses confirmed that authentic SV40 was amplified from the tumour and blood specimens.

\section{Discussion}

SV40 is capable of infecting humans, but its association with human disease remains controversial. Previous studies detected SV40 in certain human tumours, such as osteosarcoma, with controversial results $(6-8,41,46)$. Therefore, the role of SV40 in osteosarcoma development has yet to be elucidated. Additionally, data on the SV40 incidence in different populations of the investigated geographical regions are rarely 
found, making a clear decision about the role of SV40 in osteosarcoma difficult. To our knowledge, we are the first to investigate a larger number of healthy volunteers of the two countries, and compare these results with the SV40 prevalence of osteosarcoma in the two countries. Therefore, the possible role of SV40 in osteosarcoma is better understood.

Previous investigators analysing osteosarcomas used mainly conventional PCR with primers, followed by Southernblot hybridisation and occasional sequencing. Consequently, the quantification of SV40 has yet to be calculated. In this study, we investigated a very sensitive real-time quantitative PCR-Taq Man assay on the LightCycler System to re-evaluate SV40 prevalence in osteosarcoma specimens in Germany. For Hungary, only data on the SV40 antibody status in healthy people (44) exist. However, no data exist on either SV40 prevalence in osteosarcoma or SV40 quantification.

We found SV40 sequences in 114 of 154 Hungarian osteosarcomas, diagnosed between 1971 and 2001. These patients were born between 1920 and 1993. In contrast, only 30 of 166 peripheral blood samples from healthy Hungarian individuals born approximately the same period as the osteosarcoma patients (between 1919 and 1990), showed SV40 positivity. SV40-positive osteosarcoma samples were clearly positive in triplicates, each with a high copy number (>100 copies per reaction and in part $>1000$ copies), while the SV40-positive samples from healthy donors were mostly only 1 or 2 times positive in a triplicate reaction, and with a very low copy number ( $\leq 10$ copies per reaction). These findings clearly underline the difference in SV40 incidences and quantity between samples derived from osteosarcoma patients and those from healthy volunteers.

In German osteosarcoma patients, diagnosed between 1979 and 2004 (born between 1947 and 2002), 29 of 123 showed SV40 positivity: 8/60 tumour and 21/63 blood samples. The SV40-positive samples were positive 3 times in a triple test. Only 2 of 149 blood samples from German healthy volunteers showed SV40 positivity. One of these samples tested positive for 2 out of 3 reactions and the other for 1 out of 3 reactions. The same samples exhibited a very low copy number $(<10)$. Thus, we observe the same differences in SV40 incidence and quantity between samples from osteosarcoma patients and healthy people as was the case in the Hungarian samples.

SV40-positive samples of German origin have very low amounts of SV40 of $<10$ SV40 copies in 500 ng DNA while SV40-positive Hungarian osteosarcomas show a very high amount of SV40 from $>100$ copies of SV40 per reaction (500 ng DNA) and in part $>1000$ copies.

These data demonstrate significant differences in the prevalence and quantity of SV40 in osteosarcoma patients coming from different geographical regions in Europe (Hungary and Germany), with a low frequency in the peripheral blood samples of healthy people in these European countries. Possible differences in the polio vaccination programs (summarised in Table I) resulting in differences of presumably SV40-contaminated polio vaccines used, may be one reason for these data. In Hungary, inactivated (IPV) and oral polio vaccines (OPV) from Russian production were used in several periods of polio vaccination between 1959 and 1960 and after 1963, which are considered to be longer or more SV40-contaminated than vaccines produced in other countries such as Canada or Germany. In the period 1961-1962 only OPV from Hungary was used. In Germany, Canadian polio vaccines were used until 1960 followed by OPV from the German production, which was supposed to be SV40free. As reported for the USA (22), it may be possible that different levels of polio vaccines were individually administered in Germany and Hungary (e.g. in the USA, in the district of Columbia, the vaccine level varied between 0.01 and $0.97 \mathrm{ml} /$ dose). This may be another reason for the differences in SV40 prevalence between Hungary and Germany.

From the 30 SV40-positive healthy people from Hungary, 28 were born after 1938, when polio mass vaccination started in Hungary. Therefore, these 28 people were presumably vaccinated with SV40-contaminated polio vaccines (44). Six of these 30 SV40-positive healthy people were born before 1938. Consequently, they should not have received SV40contaminated polio vaccines. No sequence variations were detected among these people. Therefore, how these volunteers, born before 1938, came into contact with the SV40 virus and were infected remains unclear.

The frequency of SV40 in Hungary was nearly the same in females $(10 \%)$ and in males $(7.2 \%)$. This is in contrast to the study of Butel et al, who found a higher SV40 antibody frequency in serum samples in Hungarian female (8.9-15.6\%) volunteers than in males (2.7-2.9\%) from the group aged 36-54 years, born between 1940 and 1958, at the time of the sample collection in 1995. Regarding only the time period 1940-1958, we found 14 SV40-positive samples, 7 female and 7 male, indicating no differences in the SV40 frequency in this group. Bearing in mind that the 14 samples are half of the total (30) of the positive healthy ones from Hungary, we agree with the data of Butel et al, who also found that in this group the sera were mostly positive $(6.3-8.7 \%)$, in contrast to the other time periods which showed 1.3 or $1.4 \%$ SV40positive serum samples (44).

The positive osteosarcoma samples of Hungarian origin showed in part a very high quantity of SV40 (>100 copies per reaction) while the positivity of the healthy individuals was very low ( $\leq 10$ per reaction). Sequence analysis confirmed that the DNA detected was originally SV40.

In Hungary, paraffin-embedded osteosarcoma slices were cut off and transferred to sterile vials on different days by different technical assistants and in different laboratories of the Semmelweis University Hospital in Budapest. Therefore, SV40 contamination by cutting procedure and laboratory staff can be ruled out.

From the data obtained from the Co-operative Osteosarcoma Study Group (COSS) in Germany, it is known that the number of osteosarcomas diagnosed in a year revealed only a minor fluctuation. No peak in the osteosarcoma incidence was observed in Germany since 1980 when data collection by COSS started. In Hungary, the osteosarcoma incidence is $\sim 1.5$ osteosarcomas per 1 million people per year, resulting in $\sim 12-18$ newly diagnosed osteosarcomas per year. No peak or increase in the osteosarcoma incidence was observed since the 1970s in Hungary when data were collected. About $90 \%$ of Hungarian osteosarcomas are treated at the Semmelweis University Hospital of Budapest, from where the specimens analysed in this study were taken. 
Therefore, the osteosarcomas analysed in this investigation are a representative collective from Hungary.

To our knowledge, there is no current epidemiological study, concerning the correlation between osteosarcoma outcome and SV40 positivity, neither worldwide nor in Germany or Hungary.

The origin of SV40 infection in humans is poorly understood. SV40-contaminated polio vaccines are thought to be the main origin of this viral introduction into humans between 1955 and $1963(20,47)$. The tumour samples analysed in our study were from patients born in the periods 1920-1993 (Hungary) and 1958-1993 (Germany), many of whom received SV40-contaminated vaccines. Others may have acquired SV40 via transmission from mother-to-infant, breast-milk, or via blood transfusion, semen, faeces or sperm. Horizontal transmission following the introduction of polio vaccines may explain the presence of SV40 in younger people never directly exposed to the vaccine. Our results suggest that other sources of the virus are involved in human SV40 infection, explaining the finding of SV40 in individuals born before polio mass vaccination started, i.e. the 6 Hungarian individuals born before 1938 .

Our results confirm that geographical factors, may influence SV40 prevalence in different regions. In the USA, the incidence of SV40 sequences among osteosarcoma samples varied greatly: $40 \%$ in Massachusetts and Chicago, and $5 \%$ in Houston (6). SV40 incidence in human tumour specimens in Germany appears to be low $(48,49)$. These studies demonstrate the importance of geographical differences in detecting SV40. The reasons underlying these differences are poorly understood. However, one reason may be the polio vaccination in the period before 1965, but other additional factors cannot be excluded.

We detected SV40 not only in tumour but also in blood samples of osteosarcoma patients, indicating the possibility that the virus can circulate in these individuals.

As previously mentioned, SV40 is poorly understood. This raises a series of questions, including: i) when SV40 is carcinogenic in humans; ii) how the disease process is controlled by the virus; iii) whether it is a hit-and-run mechanism itself or whether any other events are necessary to activate SV40 in the cell, such as another alteration, e.g. on $\mathrm{p} 53$ or $\mathrm{Rb}$ in the case of osteosarcoma; iv) whether the virus replicates poorly in healthy hosts, but replicates more abundantly when host immunity is compromised; v) the circumstances regarding SV40 in the population before polio mass vaccination; vi) whether there are any additional or different ways of transmission other than blood transfusion, breast milk, human faeces and semen; vii) whether the individual's age is important for transmission; and viii) whether SV40 is a pathogen or merely a passenger.

In conclusion, this study has shown that a direct association of SV40 and osteosarcoma is not unambiguous. However, regarding the high incidence of $74 \%$ SV40 positivity in Hungary derived with RQ-PCR as a very specific detection method, and partially the very high amount of SV40 copies in Hungarian osteosarcoma samples, in contrast to the low incidence and low copy number in healthy volunteers, our data support evidence for a possible role of SV40 in osteosarcoma in Hungary. Moreover, our data suggest that SV40 is merely a bystander in osteosarcomas or in some human cancer types. Our data, however, underline that the presence of SV40 in human tumours may be influenced by geographical factors.

\section{Acknowledgements}

We thank the members the Orthopaedic Department of Semmelweis University of Budapest for providing tumour material and for clinical data. We thank all COSS centres for providing specimens used in this study. We also thank Professor Wolfgang Deppert (Heinrich Pette Institut, Hamburg) for providing the COS-1 cell line. Furthermore, we thank the Fördergemeinschaft Kinderkrebszentrum Hamburg e.V. for their financial support.

\section{References}

1. Scholz RB, Kabisch H, Weber B, Roser K, Delling G and Winkler K: Studies of the RB1 gene and the p53 gene in human osteosarcomas. Pediatr Hematol Oncol 9: 125-137, 1992.

2. Scholz RB, Christiansen H, Kabisch H and Winkler K: Molecular markers in the evaluation of bone neoplasms. In: Pathology of Bone and Joint Neoplasms. Helliwell TR (ed). WB Saunders Company, Philadelphia, pp79-105, 1999.

3. Fuchs $N$ and Winkler K: Osteosarcoma. Curr Opin Oncol 5: 667-671, 1993.

4. Mendoza S, Konishi T, Dernell WS, Withrow SJ and Miller CW: Status of the p53, Rb and MDM2 genes in canine osteosarcoma. Anticancer Res 18: 4449-4453, 1998.

5. Szendroi M: Bone tumours. Int Orthop 30: 435-436, 2006

6. Carbone M, Rizzo P, Procopio A, Giuliano M, Pass HI, Gebhardt MC, Mangham C, Hansen M, Malkin DF, Bushart G, Pompetti F, Picci P, Levine AS, Bergsagel JD and Garcea RL: SV40-like sequences in human bone tumors. Oncogene 13: 527-535, 1996.

7. Lednicky JA, Stewart AR, Jenkins JJ III, Finegold MJ and Butel JS: SV40 DNA in human osteosarcomas shows sequence variation among T-antigen genes. Int J Cancer 72: 791-800, 1997.

8. Mendoza SM, Konishi T and Miller CW: Integration of SV40 in human osteosarcoma DNA. Oncogene 17: 2457-2462, 1998.

9. Shah K and Nathanson N: Human exposure to SV40: review and comment. Am J Epidemiol 103: 1-12, 1976.

10. Cicala C, Pompetti F and Carbone M: SV40 induces mesotheliomas in hamsters. Am J Pathol 142: 1524-1533, 1993.

11. Diamandopoulos GT: Leukemia, lymphoma, and osteosarcoma induced in the Syrian golden hamster by simian virus 40 . Science 176: 173-175, 1972.

12. Diamandopoulos GT and Sanborn-Redmond S: Adenovirus-like transformation of hamster embryo cells mediated by Simian virus 40. Am J Pathol 71: 81-92, 1973.

13. Diamandopoulos GT: Induction of lymphocytic leukemia, lymphosarcoma, reticulum cell sarcoma, and osteogenic sarcoma in the Syrian golden hamster by oncogenic DNA simian virus 40. J Natl Cancer Inst 50: 1347-1365, 1973.

14. Girardi AJ, Sweet BH, Slotnick VB and Hillemann MR: Development of tumors in hamsters inoculated in the neonatal period with vacuolating virus, SV-40. Proc Soc Exp Biol Med 109: 649-660, 1962.

15. Shein HM, Enders JF and Levinthal JD: Transformation induced by simian virus 40 in human renal cell cultures. II. Cellvirus relationships. Proc Natl Acad Sci USA 48: 1350-1357, 1962.

16. Ray FA, Peabody DS, Cooper LJ, Cram LS and Kraemer PM: SV40 T antigen alone drives karyotype instability that precedes neoplastic transformation of human diploid fibroblasts. J Cell Biochem 42: 13-31, 1990.

17. Crawford LV, Cole CN, Smith AE, Paucha E, Tegtmeyer P, Rundell K and Berg P: Organization and expression of early genes of simian virus 40. Proc Natl Acad Sci USA 75: 117-121, 1978.

18. Carbone M, Rizzo P, Grimley PM, Procopio A, Mew DJ, Shridhar V, de Bartolomeis A, Esposito V, Giuliano MT, Steinberg SM, Levine AS, Giordano A and Pass HI: Simian virus-40 large-T antigen binds p53 in human mesotheliomas. Nat Med 3: 908-912, 1997. 
19. De Luca A, Baldi A, Esposito V, Howard CM, Bagella L, Rizzo P, Caputi M, Pass HI, Giordano GG, Baldi F, Carbone M and Giordano A: The retinoblastoma gene family $\mathrm{pRb} / \mathrm{p} 105$, p107, pRb2/p130 and simian virus-40 large T-antigen in human mesotheliomas. Nat Med 3: 913-916, 1997.

20. Butel JS and Lednicky JA: Cell and molecular biology of simian virus 40: implications for human infections and disease. J Natl Cancer Inst 91: 119-134, 1999.

21. Fisher SG, Weber L and Carbone M: Cancer risk associated with simian virus 40 contaminated polio vaccine. Anticancer Res 19: 2173-2180, 1999.

22. Fraumeni JF Jr, Ederer F and Miller RW: An evaluation of the carcinogenicity of simian virus 40 in man. JAMA 185: 713-718, 1963.

23. Geissler E: SV40 and human brain tumors. Prog Med Virol 37: 211-222, 1990.

24. Melnick JL and Stinebaugh S: Excretion of vacuolating SV-40 virus (papova virus group) after ingestion as a contaminant of oral poliovaccine. Proc Soc Exp Biol Med 109: 965-968, 1962.

25. Domok I, Molnar E and Jancso A: Virus excretion after mass vaccination with attenuated polioviruses in Hungary. Br Med J 1: 1410-1417, 1961.

26. Sweet BH and Hilleman MR: The vacuolating virus, S.V. 40 Proc Soc Exp Biol Med 105: 420-427, 1960.

27. Bergsagel DJ, Finegold MJ, Butel JS, Kupsky WJ and Garcea RL: DNA sequences similar to those of simian virus 40 in ependymomas and choroid plexus tumors of childhood. N Engl J Med 326: 988-993, 1992.

28. Carbone M, Rizzo P and Pass HI: Simian virus 40, poliovaccines and human tumors: a review of recent developments. Oncogene 15: 1877-1888, 1997.

29. Mutti L, Carbone M, Giordano GG and Giordano A: Simian virus 40 and human cancer. Monaldi Arch Chest Dis 53: 198-201, 1998.

30. Weiss R, Giordano A, Furth P, DeCaprio J, Pipas J, Ozer H, Strickler H, Procopio A, Garcea R and Carbone M: SV40 as an oncogenic virus and possible human pathogen. Dev Biol Stand 194: 355-360, 69-82, 1998.

31. Carbone M, Rizzo P and Pass H: Simian virus 40: the link with human malignant mesothelioma is well established. Anticancer Res 20: 875-877, 2000.

32. Gazdar AF, Butel JS and Carbone M: SV40 and human tumours: myth, association or causality? Nat Rev Cancer 2: 957-964, 2002.

33. Garcea RL and Imperiale MJ: Simian virus 40 infection of humans. J Virol 77: 5039-5045, 2003.

34. Vilchez RA, Kozinetz CA, Arrington AS, Madden CR and Butel JS: Simian virus 40 in human cancers. Am J Med 114: 675-684, 2003

35. Vanchiere JA, White ZS and Butel JS: Detection of BK virus and simian virus 40 in the urine of healthy children. J Med Virol 75: 447-454, 2005.
36. Paracchini V, Garte S, Pedotti P and Taioli E: Review of prevalence of Simian virus 40 (SV40) genomic infection in healthy subjects. Mutat Res 612: 77-83, 2005.

37. Paracchini V, Garte S, Pedotti P, Poli F, Frison S and Taioli E: Molecular identification of Simian virus 40 infection in healthy Italian subjects by birth cohort. Mol Med 11: 48-51, 2005.

38. Lednicky JA, Garcea RL, Bergsagel DJ and Butel JS: Natural simian virus 40 strains are present in human choroid plexus and ependymoma tumors. Virology 212: 710-717, 1995.

39. Butel JS, Arrington AS, Wong C, Lednicky JA and Finegold MJ: Molecular evidence of simian virus 40 infections in children. J Infect Dis 180: 884-887, 1999.

40. Jasani B, Cristaudo A, Emri SA, Gazdar AF, Gibbs A, Krynska B, Miller C, Mutti L, Radu C, Tognon M and Procopio A: Association of SV40 with human tumours. Semin Cancer Biol 11: 49-61, 2001

41. Heinsohn S, Scholz RB, Weber B, Wittenstein B, Werner M, Delling G, Kempf-Bielack B, Setlak P, Bielack S and Kabisch H: SV40 sequences in human osteosarcoma of German origin. Anticancer Res 20: 4539-4545, 2000.

42. Heinsohn S, Golta S, Kabisch H and zur Stadt U: Standardized detection of Simian virus 40 by real-time quantitative polymerase chain reaction in pediatric malignancies. Haematologica 90: 94-99, 2005.

43. McNees AL, White ZS, Zanwar P, Vilchez RA and Butel JS: Specific and quantitative detection of human polyomaviruses BKV, JCV, and SV40 by real time PCR. J Clin Virol 34: 52-62, 2005.

44. Butel JS, Wong C, Vilchez RA, Szucs G, Domok I, Kriz B, Slonim D and Adam E: Detection of antibodies to polyomavirus SV40 in two central European countries. Cent Eur J Public Health 11: 3-8, 2003.

45. Gluzman Y: SV40-transformed Simian cells support the replication of early SV40 mutants. Cell 23: 175-182, 1981.

46. Butel JS, Jafar S, Stewart AR and Lednicky JA: Detection of authentic SV40 DNA sequences in human brain and bone tumours. Dev Biol Stand 94: 23-32, 1998.

47. Carbone M, Fisher S, Powers A, Pass HI and Rizzo P: New molecular and epidemiological issues in mesothelioma: role of SV40. J Cell Physiol 180: 167-172, 1999.

48. Weggen S, Bayer TA, von Deimling A, Reifenberger G, von Schweinitz D, Wiestler OD and Pietsch T: Low frequency of SV40, JC and BK polyomavirus sequences in human medullo-blastomas, meningiomas and ependymomas. Brain Pathol 10: 85-92, 2000.

49. Montesinos-Rongen M, Besleaga R, Heinsohn S, Siebert R, Kabisch H, Wiestler OD and Deckertm M: Absence of simian virus 40 DNA sequences in primary central nervous system lymphoma in HIV-negative patients. Virchows Arch 444: 436-438, 2004. 